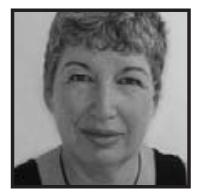

\title{
Research as Experience and the Experience of Research: Mutual Shaping in the Arts and in Qualitative Inquiry
}

Liora Bresler, University of Illinois at Urbana-Champaign

\section{ABSTRACT}

This paper examines the experience of being a researcher and how this experience shapes who we are in a process of mutual shaping. The very engagement with research, the author suggests, parallels the engagement with music and the arts. In this engagement, problem setting and problem solving, the conceptual and the embodied, the analytic and the holistic, are interconnected and interdependent. Assuming the role of an animator, the communication of the research intensifies our engagement, contributing to the shaping of who we are.

\section{Overture}

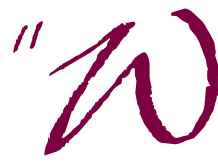

e teach who we are," wrote Parker Palmer (Palmer, 1998, p. 2), famously, making a case that teachers' "inner landscapes" are central to what they do. Other occupations, too, to various extents, are shaped by those who "occupy" them. Indeed, one can distinguish occupations by the degree to which they offer opportunities to express who one is. Being an artist is an obvious example of an occupation that allows space to express who one is. As importantly, who one is is shaped by his or her artistic experiences. In this paper I suggest that researchers, too, like artists and teachers, "research who we are," and in turn, are shaped by this experience. 
The inclusion of the experience of being a researcher in qualitative research accounts is relatively recent, arising out of the postmodern realization that in the social sciences, the researcher is the main instrument. In a constructivist worldview, interpretive research begins with the biography and the self of the researcher (Denzin, 1989). Examining the self interacting with the data is essential to interpretations (Guba \& Lincoln, 1994; Peshkin, 1988a).

Traditionally, research reports have provided little information about the researchers and the ways that their understandings were shaped by their biographies and their research experiences. In the past 40 years, however, interpretive ethnography has taken a more reflexive stance, with its critical examination of the anthropologist's presence and actions, and its interest in the ways that self and others are mutually shaped in the process of fieldwork. As producers and consumers of ethnographic accounts, we now want to know more, in more depth, and from a more self-reflexive standpoint, about the authors' subjectivity, their interactions with participants, the ethical dilemmas the researchers faced in the course of their work, and how these were handled. A more reflexive anthropology has also meant a greater concern with the recursive nature of fieldwork, that is, the reciprocal relationship between the ways fieldwork unfolds and the tools that the ethnographer employs (Bresler, Wasser, Hertzog, \& Lemons, 1996). This relationship underlies the process of interpretation.

This paper takes yet another step in the direction of examining the role of the experience of research. I suggest here a focus on the experience of being a researcher and on how this experience shapes who we are. I call this mutual shaping. There is a long tradition, at least from the $19^{\text {th }}$ century, of literature on such mutual shaping in the arts: the experience of artists and how this experience shapes creative expression. I noted above the emerging literature on how researchers' subjectivity shapes research (e.g., Peshkin, 1988a; 1988b; Feuerverger, 2001). However, there seems to be little written about the other half of mutuality, that is, how researchers are shaped by their research.

The parallel between occupations in the arts and in research runs on yet another, finer level. The very engagement with research, I suggest, parallels the engagement with music and the arts. In this engagement, problem setting and problem solving, the conceptual and the physical, the analytic and the holistic, are interconnected and interdependent. The communication of the work with fellowresearchers and with audiences intensifies the engagement, contributing to the shaping of who we are. 
As those involved in the process of doing research, it behooves us therefore to examine the experience of being a researcher. The goal of this paper is to invite such explorations. In so doing, I draw on writings about the making of art and about art appreciation, as well as on my own experiences as a musician and a pianist, in the tradition of self-study (e.g., Bruner, 1996). While self-study researchers acknowledge the role of the self in the research project, they focus on the space between self and the practice in which one engages (Bullough \& Pinneagar, 2001). Unlike Escher's (1948) self-referential hand drawing itself (http://www.worldofescher.com/ gallery/A13.html), emerging from a sleeve situated on a blank page in a featureless base, the self-study researcher operates in a specific context, addressing specific research questions, involving specific participants. Going beyond oneself and navelgazing, the focus is on the interaction with a dynamically changing world and self.

Parallelism does not imply equivalence. Instead, it aims to propose fresh issues for reflection and discussion. This is what this paper sets out to do. The theme of parallel processes between the arts and research has invited the counterpoint-like writing style of this paper, with the weaving together of two sets of experiences, engagement in the arts and engagement in research, parallel yet each displaying an individual and differentiated contour.

\section{Engagement, Exploration, and Craft}

While textbooks on teaching research methods abound, including some excellent works, these are but guiding texts. Ultimately, the researcher is left in the field on her own, to conceive of interesting and important research questions, to craft a study that will be responsive to the research goals, to the setting and participants, and that, not less important, will satisfy advisor, committee members, and the researcher herself! The conceptualization of qualitative research precedes and emerges through the actual conduct of research in what is typically a process of prolonged engagement. In qualitative research, data collection and analysis overlap. Design is responsive to participants' stories and observations (Bresler, 1997).

The textbook methods of research commonly provide some general guidelines on how to take field notes (e.g., Bogdan \& Biklen, 2003; Emerson, Fretz, \& Shaw, 1995); how to interview (e.g., Kvale, 1998; Spradley, 1979); and how to analyze data (e.g., Miles \& Huberman, 1984; Patton, 2002). These provide useful tools that help researchers get oriented, structure observations, focus, and construct interviews that 
have coherence. Beyond this level of methods, most crucial is allowing a space for the setting to present its unfolding story, and a space for participants to lead us into topics and areas whose "compellingness" we could not have anticipated. This open-endedness, I have found time and again, enables me to comprehend a perspective different from my own. It takes an attentiveness, a responsiveness, to emic, insiders' voices, and to an etic/emic interplay where I am expanded not only by findings to my original questions, but also where the questions themselves, my curiosities and wonderments, are expanded. To provide a specific example: in my study of arts education (Stake, Bresler, \& Mabry, 1991), my initial questions addressed the nature of the operational and perceived curriculum in elementary schools. As I observed and talked with the teachers participating in my study, I noted a discrepancy between teachers' arts practice (mostly teacher-centered and rote), and what they shared as their views of arts (the arts as highly affective, and a tool to cultivate self-expression). This discrepancy became a focus for further inquiry.

Engagement in music, such as performing, involves a discernment of melodic lines, rhythms, and harmonic progressions, in order to create an expressive whole. When confronted with a new musical style that lies out of immediate likes (I recall, for example, practicing my very first Stockhausen), the analytic and conceptual are crucial in making sense and befriending the music. Whether parts to whole, or whole to parts, the process of connection and crafting an interpretation is never linear, always iterative.

As I became acquainted with key scholars of visual art education, I realized that musical analysis has its visual equivalents. Feldman (1967), for example, identified the elements of grammar (shape, light and dark, color, texture); organization of artistic elements (unity, balance, rhythm, proportion); and aesthetics (empathy, psychic distance, fusion, and good gestalt) as analytic tools in art appreciation. Broudy (1972) coined the term scanning, focusing on similar parameters, categorized as sensory, technical, formal, and expressive qualities.

Similarly, in doing qualitative research, the analytic tool of scanning helps structure observation as well as data analysis. We attend to the sensory aspects and (the metaphorical) qualities of shapes, and textures of education. We investigate formal qualities, the relationships between occurrences (e.g., teachers' actions, students' behaviors and experiences,) and how they are organized. We reflect on the expressivity and the meaning of curriculum and the teaching. 
In his book Move closer: An intimate philosophy of art, art appreciation scholar Armstrong (2000) identifies five aspects of the process of perceptual contemplation of an artwork: 1. noticing detail, 2 . seeing relations between parts, 3. seizing the whole as the whole, 4 . the lingering caress, and 5. mutual absorption. The first three, which correspond to musical analysis tools and the ones established by Feldman and Broudy, also apply to the conduct of research. Noting the sensory, formal, and expressive qualities of research, as well as looking at the expressivity and meaning of the case as a whole, is an example of how these aspects can support the conduct of research.

The last two aspects, lingering caress and mutual absorption, evoke different kinds of relationships in the experiential encounter with artwork. They point at dialogical relationships, where, in addition to being task oriented, the viewer opens to a receptive mindset, to be changed by the encounter. Lingering caress is characterized by the lack of instrumental purpose-a form of engagement which is traditionally associated with the concept of aesthetics. When we linger, Armstrong notes, "Nothing gets achieved, nothing gets finished - on the contrary, satisfaction is taken in spinning out our engagement with the object" (Armstrong, 2000, p. 98). The process of a deepening relationship allows for artistic and aesthetic discoveries. The same lingering associated with the concept of art, I suggest, is crucial in research. The cycles of data collection and noting, intertwine with the more leisurely cycles of immersion with the data, letting it sink in and speak to us, to dialogue with our assumptions, values, thoughts and feelings. I find that this is where the growth happens, where I get off my own "beaten track" of thoughts into fresh paths.

The fifth aspect, mutual absorption, refers to the transformative character of this deep engagement. Armstrong writes, "When we keep our attention fixed upon an object which attracts us, two things tend to happen: we get absorbed in the object and the object gets absorbed into us" (p.99). In my own experience of mutual absorption in music, whether with Bach, Schubert or Ligeti, I "become the music."The boundaries between what I commonly perceive as inside me and outside me are blurred. Sound penetrates the self, engaging me on bodily, mind and spirit levels.

Mutual absorption takes, I believe, a heightened form in the process of making and creating. I think of that process as mutual shaping. I have experienced it in the act of performing music and the construction of musical interpretations, a process in which I am affected by the sounds and interpretations I create. Similarly, I find that as I construct ideas, issues and interpretations in research, these ideas and interpretations expand my conceptualizations, and as importantly, my understanding, enabling 
me to gain empathy for a perspective foreign to my own. ${ }^{1}$ This dialogical space, where I interact with materials and generate ideas in a process of forming and reforming, becomes, as I discuss in the next section, tri-directional in the process of communicating to others.

Making in music commonly takes the form of performance, improvisation and composition. In qualitative research, there are three interdependent levels of making. There is the research process: the conduct of observations, the interviewing, what we commonly refer to as "fieldwork." There is data analysis with its different forms and stages. And there is the writing. The writing is based on the fieldwork, though writing can also lead the interaction. Wolcott (2002) recommends that researchers start with writing as a way to articulate their preconceptions, and only then move on to fieldwork.

Making, whether in music, in visual art, or in research, requires craft. There is no art without craft, writes sociologist Sennett: the idea of a paper is not a paper; the idea of a musical composition is not a musical composition (Sennett, 2008, p. 65). Craft, whether in musical performance or in research, is founded on skill developed to a high degree. Skill is a trained practice. Materials are central. Just as becoming a musician involves proficiency with a voice or an instrument, becoming a researcher requires proficiency with the materials and the craft of research. The craftsman's efforts to do good quality work and shape materials depend on curiosity about the material at hand, curiosity generating (and generated by) an interaction and a dialogue. The line between craft and art may seem to separate technique and expression but this separation is false. ${ }^{2}$

While we often imply technical accuracy and the notion of utilitarianism when we use the word craft instead of art, the Greek origin behind our use of the words technology, technique and technical suggest there is more to examine. To the Greeks, there was no distinction between art and craft; it was all techne, a term they used to indicate that we make form visible, whether drama, weaving or recitation. Techne meant a good fit between the form of the idea and the use. So, craft at its best is bringing forth the form, and doing so in a manner that animates it. ${ }^{3}$ Fieldwork (interviews and observations), data analysis, and writing, are critically dependent on craft. Craft in research is acquired by coursework, readings and practice, mediated by cognition, emotion as well as intuition. But to be at its best, the craftsman's deft use of tools and materials, combined with an intuition developed from years of knowing the craft, create a reciprocity that animates the form. It is the matter of using cognition to cast intuition and emotional resonance with the research, getting into origi- 
nal and interesting research questions, as well as the aspiration to understand what is unknown. The craftsman, musician or researcher can possibly pattern herself after the form she feels, thus giving form to one's soul in the process.

Sennett uses the example of pottery, where raw clay is "cooked" both by the tools that shape it into a pot and by the kiln, which does the literal work of cooking. Cooked clay provides a medium for making images that, on a pot, create a narrative as the pot is turned. This narrative can travel and it can be traded or sold as a cultural artifact. Clay, Sennett claims, is "good to think with," quoting Levi-Strauss that symbolic value is inseparable from awareness of the material condition of an object; its creators thought the two together (Sennett, 2008, p. 129). Sennett argues that the craftsman, engaged in a continual dialogue with materials, does not suffer the divide of understanding and doing. The craftsman, writes Sennett, must be patient, avoiding quick fixes. Good work of this sort emphasizes the lessons of experience through a dialogue between tacit knowledge and explicit critique (Sennett, 2008, p. 51).

Musical craft follows a similar route. My initial engagement, exploration and cultivation of musical skills were acquired in playing piano as a young child, before my formal music education had started. These skills involved playing by ear, picking up melodies and harmonies to match. This stage of learning, though intense and powerful, was informal, implicit and untested. Comprising of knowledge of sound, musical phrases, rhythm, and harmony, the learning was characterized by a heightened experiential quality, a quality that is often related to a musical community. Technique and expression were interwoven. Later on, in my formal training, technique did assume the narrower meaning of an imposition of a form, separate from experience in what Dewey (1938) would have classified as miseducation.

Miseducation is always a danger of academic learning, including in the teaching and learning of research methods. As a teacher of research, I strive to go beyond the narrow definition of methods. I also attempt to cultivate in my students the harnessing of cognition to their deeper curiosity and aspiration to understand. Craft in research, I suggest, involves self-cultivation. Research materials consist of observations and interviews - fundamental to social interactions and to learning in its deepest sense. Becoming proficient in the subtle experiences of observing and listening (a practice that is never complete) and in the interplay of the concreteness of a specific situation, with the abstraction of issues, are skills useful in our everyday interactions. 
A continual dialogue with materials necessitates a capacity for sustained attention. Attention is at the core of perception and exploration, and the building block of intimacy, wisdom and cultural progress. Attention, writes William James, "is the taking possession by the mind, in clear and vivid form, of one out of what seem several simultaneous possible objects of trains of thought. It implies withdrawal from some things in order to deal effectively with others" (quoted in Jackson, 2008, p. 13). The opposite of attention is the scatterbrained state of distraction. Jackson (2008) portrays the increased states of distraction in our society where we are pulled constantly by virtual universes, the addictive allure of multitasking people and things in a constant state of motion.

Distraction, indeed, increasingly part of academic life, is the enemy of scholarship. The musical engagements of focused listening and performing, I realized, provided me with models for sustained attention in research. In music, attention comes in different forms. There is the holistic listening, when a musical piece captivates. Another type of attention is required in encountering a new piece where the analytic mode takes the forefront. The attention of the analysis is different from the attention of the lingering caress, and these two are different from the attention involved in embodying the piece as we learn to perform it. These forms of attention have their equivalents in the practice and conduct of research.

The relationships implicated in the act of making, interactive and recursive, rather than hierarchical and linear, go beyond methods. The encounter with musical and artistic materials requires dialogic relationships, paralleling the researcher's encounter with setting and participants, or the scholar's craft of words to shape ideas and issues in the research document. These aspects infuse the various stages of qualitative research, including the processes of interviewing, analysis and writing. In my own experience, research often starts with lingering, a space to identify what is compelling, what calls for a deepening of understanding and sustained investigation. Once a focus has been determined, it functions as a starting point, to be reconsidered and revised as the relationships with participants and data, rather than a definitive end point. The initial stages of fieldwork are typically analytic and task oriented, with the focus on detail, noting relations and patterns, and grasping for meaning and interpretations. The lingering aspect is ever present-from the preliminary data analysis of the contact summary sheet to the interim reports (Miles \& Huberman, 1984) - in preparing for the next cycle of observation or interviews, till after the paper has been published, when my relationships with it can still evolve, taking me to the next presentation or paper. 
The craft and the interaction with materials exist, of course, beyond qualitative inquiry, in diverse types of research. A well-known example is Nobel Prize winner Barbara McClintock's work in genetics. McClintock did not approach her research with a pedestrian textbook notion that her task was to analyze it into data bits. Instead, she approached genetic material by observing how genes function in their environment rather than regarding them merely as isolated entities, and in the process, discovered that bits of genes can move about on chromosomes (Fox Keller, quoted in Palmer, 1998, p. 55.). When Evelyn Fox Keller interviewed McClintock in order to write her biography, it became clear that McClintock's work went beyond the relationships among genes to include the relationship between the genes and the scientist who studied them. When asked what enabled McClintock to make her discoveries, McClintock emphasized the need to cultivate the patience to "hear what the material has to say to you," the openness to "let it come to you." "Clearly, it took extensive knowledge and sophisticated analytic skills," writes Palmer, "data and logic and the distance they provide are only one pole of the paradox of great science." Indeed, in the arts, as in research, connectedness is not the opposite of formal skills but complements them (Palmer, 1998). ${ }^{4}$

\section{Communication in Music and in Research: The Researcher as an Animator}

The dialogue between the musician and the music, artist and artwork, anticipates communication. My own experiences of performing classical music involve three primary gestures: (i) absorption--looking at the score, ${ }^{5}$ aiming to comprehend it and get it as accurately as possible; (ii) introspection and synthesis--reaching into my inner landscapes, searching for resonance, resistance, emotional and intellectual resources to comprehend and relate to; and (iii) communication--reaching to the audience in trying to communicate the newly cultivated understanding. Research, too, consists of these three gestures: (i) absorption--reaching towards the phenomena under study to understand it as accurately and fully as possible; (ii), introspection and synthesis--reaching into oneself, drawing on our inner landscapes of subjectivities, and values, to make meaning; and (iii), communication--reaching to our audience. ${ }^{6}$ In qualitative, "human science" research, the final product is evaluated not only by its correctness, but also by its depth and the resonance it creates in others. These three gestures coexist, building on and supporting each other. Accuracy has a specific focus. Going inside requires depth and introspectiveness that, indeed, enable us to 
bring to our interactions with the arts and research who we are. Communication to others traverses personal and spatial boundaries. The anticipation of an audience shapes and directs the work of musical performer.

My earlier example of playing folksongs as a child exemplifies the interrelationship between learning and performance. Picking up melodies and harmonies was closely followed by performing these songs in home and preschool gatherings to accompany singing of Israeli folksongs. These performances informed the next cycle of playing by ear and learning more melodies. Here, the cultivation of skills and craft involved recursively listening to the music, practice, connection and communication through lived musical encounters, in relationships with a keen community of singers.

I find a similar close interaction between craft and communication in my research practice. The awareness of the audience in research is present at various stages, way before the actual communication. The process of research, like musical performances, involves the discovery and shaping of meaning for oneself as well as for others. Already in the early stages of fieldwork, the observations attend to what is observed, but are shaped by the prospect of its communication to others. Ethnographers are propelled by intellectual-emotional curiosity, intensified with the commitment to an outside audience. Losing that sense of audience can be experienced as losing their raison d'être as ethnographers, or "going native." In the worlds of professional music and professional research, it is the acts of communication that give both performance and research meaning (and the institutional validation that is an essential part of these professions). The awareness of a potential audience, I find in my own work, heightens perception, rendering what could be a lonely activity into a social one, part of community making.

Performance is a heightened experience. Stubley quotes Dolores Grondal's description of performance as a "way of being." In the process of discovering and shaping the music, the performer lives in and through it. Quoting Ricoeur, the self is both actor and observer (in Stubley, 1995, p. 64). The aesthetics of communication involves an embodied cognition and affect. As classical performers know, losing aesthetic distance during performance-being swept away by our feelings - is risky. In research, this self-expression can take the form of advocacy. More often in communicating research, the delicate balance between emotion and cognition loses the emotive aspect. 
Communication to others, that delicate dialectical interplay between the private and the public, is at the heart of qualitative research and teaching. Learning to negotiate these intersections, artistic and musical experiences can provide rich materials from which to learn. They involve concentrated, sustained focus and perception that often leads to personal transformation, juxtaposing cognition and affect.

I have struggled for some time with the right image for the communicator of research: composer? performer? conductor? first violinist? Miller and Boud (1996), highlighting the role of experience in teaching, and focusing on activities that create circumstances in which others can learn, came up with the notion of the animator. They draw on the connotations of the word, which include, among others, "to give life to," "to quicken," "to vivify," "to inspire," and "to activate." Miller and Boud refer to the function of working with the experience of others as animation (1996, p. 7), and to the person who works to promote others' learning as an animator. They see the function of animators to be that of acting with learners, or with others, in situations where learning is an aspect of what is occurring (Miller \& Boud, 1996, p. 7). This image fits with my image of the musician, and directly relevant to this discussion, to the researcher as communicator, as creator of experiences.

\section{Collaborating in Music and in Research}

In collaborative research, the three primary gestures of solo music (absorption, introspection and synthesis, and communication) become a four. Added is the collaboration with other researchers. There is increasing recognition in the social sciences of the collective nature of knowing and social theories of development, but little about the role that researchers' interactions with each other play in the coconstruction of knowledge. ${ }^{7}$ Chamber music provides us with the metaphor for an "interpretive zone" (Wasser \& Bresler, 1996), ${ }^{8}$ the intellectual realm in which researchers work collaboratively. The concept of zone assumes more than one party-at least two if not more-negotiating, and interacting from different perspectives. Thus, the term zone, more than the term interpretation, moves us away from the traditional image of the researcher as a soloist working independently to that of a socially embedded researcher grounded in social interactions. As in a chamber ensemble, the notion of zone implies dynamic processes-exchange, transaction, transformation, and intensity. In the interpretive zone researchers bring together their distinct voices - various areas of knowledge, experience, and beliefs, to forge new meanings through the process of the joint inquiry in which they are engaged. 
Harmonies range from neutral (scaffolding), through conflict (struggles), to amicable (negotiations). These same qualities characterize research groups. It is the unexpected meeting between different ideas and perspectives that breaks new intellectual ground.

\section{Coda}

I opened the paper suggesting we research who we are. Paralleling experiences in the arts, research is shaped by exploration, engagement and craft. It moves recursively among the phases of absorption, introspection and synthesis, supported by a collaborative zone and communication. Mediated by cognition and lingering caress, it is inspired by the deep wish to understand. Ultimately, as the research unfolds, in the process of mutual shaping, we also research who we may become.

\section{Notes}

I am indebted to Ma'ayan Bresler, Yoram Bresler, Chris Higgins, and Sally Gradle for their reading of this paper and insightful comments.

1. This reminds me of Goldsworthy's comment (2004, quoted in Barrett 2007, p. 644) that "art-making is a process of discovery, rather than a rendering of preconceived knowledge or experience. The artist is making art in order to better understand what he is making art about. Through his art-making the artist comes to a better understanding of an aspect of the world and how to render it in visual form."

2. A misperception I, too, have shared as I was trying to distinguish between different types of arts curriculum, mistaking craft for "rote" and technical (Bresler, 1998). I am grateful to John White for a conversation that sensitized me to the complexity and the richness of craft and to Sally Gradle for sharing her insights on craft.

3. I am indebted to Sally Gradle for this observation. 
4. I have elaborated on the place of connectedness in qualitative methodology in Bresler, 2006.

5. Sometimes preceded by being reached by the music, in which the process is bidirectional.

6. These three aspects are also central to teaching (Bresler, in press.)

7. This includes theoretical and practical work on the nature of groups and interpretation in diverse fields, including anthropology, the sociology of science and clinical psychology.

8. We drew on scholarly uses of the term including Vygotsky's zone of proximal development (1986), Bakhtin's character zones (1986), Pratt's linguistic contact zones (1992), and Giroux's (1992) border zones.

\section{References}

Armstrong, J. (2000). Move closer: An intimate philosophy of art. New York: Farrar, Straus, \& Giroux.

Bakhtin, M. (1986). Speech genres and other late essays. (V. McGee, Trans., C. Emerson, \& M. Holquist, Eds). Austin: University of Texas Press.

Barrett, T. (2007). Teaching toward appreciation in the visual art. In L. Bresler (Ed.), The handbook of research in arts education. (pp. 639-654). Dordrecht, NL: Springer.

Bogdan, R., \& Biklen, S. (2003). Qualitative research for education: An introduction to theories and methods. New York: Allyn \& Bacon.

Bresler, L. (1997). Towards the creation of a new code of ethics in qualitative research. Council of Research in Music Education, 130, 17-29.

Bresler, L. (1998, Sep/Oct). "Child art," "fine art," and "art for children": The shaping of school practice and implications for change. Arts Education Policy Review, 100(1), 3-10.
Bresler, L. (2006). Embodied Narrative Inquiry: A Methodology of Connection. Research Studies in Music Education, 27, 21-43.

Bresler, L. (in press/January 2009). Research Education Shaped by Musical and Aesthetic Habits of Mind. To appear in the British Journal of Music Education, 26(1).

Bresler, L., Wasser, J., Hertzog, N., \& Lemons, M. (1996). Beyond the lone ranger researcher: Teamwork in qualitative research. Research Studies in Music Education, 7, 15-30.

Broudy, H. (1972). Enlightened cherishing: An essay on aesthetic education. Urbana: University of Illinois Press.

Bruner, E. (1996). My life in an Ashram. Qualitative Inquiry, 2(3), 300-319.

Bullough, R.V., \& Pinneagar, S. (2001). Guidelines for quality in autobiographical forms of self-study research. Educational Researcher, 30(3), 13-22.

Denzin, N. K. (1989). Interpretive interactionism. Thousand Oaks, CA: Sage. 
Dewey, J. (1938). Experience and education. New York: MacMillan.

Emerson, R., Fretz, R., \& Shaw, L. (1995). Writing ethnographic fieldnotes. Chicago: University of Chicago Press.

Escher, M.C. (1948). Drawing hands [signature poster]. Retrieved October 7, 2008, from the World of Escher Web site: http://www.worldofescher.com/gallery/ A13.html

Feldman, E. B. (1967). Varieties of Visual Experience: Art as image and idea. Englewood Cliffs, N.J.: Prentice-Hall.

Feuerverger, G. (2001). Oasis of dreams: Teaching and learning peace in a Jewish-Palestinian village in Israel. New York: Routledge.

Giroux, H. (1992). Border crossings. New York: Perigee Books.

Guba, E. G., \& Lincoln, Y. S. (1994). Competing paradigms in qualitative research. In N. K. Denzin \& Y. S. Lincoln (Eds.), Handbook of qualitative research (pp. 105-117). CA: Sage Publications, Inc.

Jackson, M. (2008). Distracted: The erosion of attention and the coming dark age. Amherst, NY: Prometheus Books.

Kvale, S. (1996). InterViews. Thousand Oaks, CA: Sage.

Miles, M. B., \& Huberman, A. (1984). Qualitative data analysis. Beverly Hills, CA: Sage.

Miller, N., \& Boud, D. (1996). Animating learning from experience. In D. Boud \& N. Miller (Eds.), Working with experience: Animating learning (pp. 3-13). London: Routledge.

Palmer, P. J. (1998). The courage to teach: Exploring the inner landscape of a teacher's life. San Francisco: Jossey-Bass Publishers.
Patton, M. Q. (2002). Qualitative research and evaluation methods. Thousand Oaks, CA: Sage.

Peshkin, A. (1988a). In search of subjectivity One's own. Educational Researcher, 17(7), 17-21.

Peshkin, A. (1988b). God's choice: The Total world of a fundamentalist Christian school. Chicago: The University of Chicago Press.

Pratt, M. (1992). Imperial eyes. New York: Routledge.

Sennett, R. (2008). The Craftsman. New Haven: Yale University Press.

Spradley, J. P. (1979). The ethnographic interview. New York: Holt, Rinehart and Winston.

Stake, R., Bresler, L., \& Mabry, L. (1991). Custom and cherishing: The arts in elementary schools. Urbana: University of Illinois, Council for Research in Music Education.

Stubley, E. (1995). The performer, the score, the work: Musical performance and transactional reading. Journal of Aesthetic Education, 29(3), 55-69.

Vygotsky, L. (1986). Thought and language (A. Kozulin, Trans. \& Ed.). Cambridge, MA: Cambridge University.

Wasser, J., \& Bresler, L. (1996). Working in the interpretive zone: Conceptualizing collaboration in qualitative research teams. Educational Researcher, 25(5), 5-15.

Wolcott, H. (2002). Writing up qualitative research. Thousand Oaks, CA: Sage. 


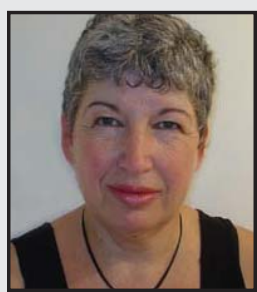

Liora Bresler is a Professor at the College of Education at the University of Illinois at Urbana-Champaign. Most recently, she has edited the International Handbook of Research in Arts Education (2007, Springer), Knowing bodies, moving minds: Towards embodied teaching and learning (2004, Kluwer), The arts in children's lives: Context, culture, and curriculum (Bresler \& Thompson, 2002, Kluwer) and International Research in Education (Bresler \& Ardichvili, 2002, Peter Lang). Bresler serves as an editor for the book series: Landscapes: Aesthetics, Arts and Education, for Springer. She is the cofounder and coeditor of the International Journal for Arts and Education. 